\title{
"Working Capital Management and Firms Financial Performance of Oil Companies in Nigeria"
}

\author{
Ironkwe, Uwaoma. I. Ph.D ${ }^{1}$, Wokoma, David .A. ${ }^{2}$ \\ ${ }^{1}$ Department of Accounting, Faculty of Management Sciences, University of Port Harcourt, Port Harcourt, \\ Nigeria \\ ${ }^{2}$ Department of Accounting, Faculty of Management Sciences, University of Port Harcourt, Port Harcourt,
} Nigeria

\begin{abstract}
The research examined the connection amid Working Capital Management (WCM) in addition to Financial Performance of Oil companies in Nigeria. The Quasi-Experimental design was employed. The hypotheses were tested by using the Pearson Product Moment Correlation (PPMC). Data analysis results point to that of a progressive and perfectly substantial relationship amongst investing and financing rules and Return on Assets (ROA) exists; a neutral and minor relationship amid both financing and investing policies and earnings per share (EPS) exists. Furthermore, there is an insignificant but undesirable relationship amongst investing and financing rules and return on equity (ROE). Conclusively, WCM impacts performance of Nigerian firms primarily from the domain of ROA. It is recommended amongst others that the comprehensive appraisal of fiscal performance trends and WCM framework; Firms in the sector should establish adequate benchmarks of working assets components in order for emerging obligations to be met adequately.
\end{abstract}

Keywords: EPS, Financial Policy, Investing Policy, Nigeria, ROA, ROE, Oil Companies,

Overview

\section{Introduction}

\subsection{Background to the Study}

It is a generally accepted fact that proper managing of operational capital is vital to a firm's fundamental fiscal health and operative success as an industry. A trademark of noble business is hinged on management to utilize a solid balance amongst growth, liquidity and viability. A prominent challenge of organizations in the oil and gas sector is achieving the desired trade off between the aforementioned (Lazaridis et al., 2007). Management is therefore essential for sound financial recital for profitability of the company (Rajesh and Ramana Reddy, 2011). For investors, their monies is extremely valuable, and a well performing industry can convey high and long-standing returns for their investors. Furthermore, fiscal profitability will boost employees earnings, bring better value products for its clients, and require better environment friendly manufacture units. Also, more profits will mean extra future savings, which generate and improve the earnings of persons.

Onwumere et al (2012) carried out a preliminary investigation on Nigerian selected Firms for a fiveyear period from 2004to 2008. Imeokparia (2015) examined the Nigerian stock exchange in relation to management capital. It was also examined in relation to efficiency, profitability and liquidity. Yahaya and Bala (2015) investigated working capital over six years. They identified current and quick ratios as dimensions of capital management work. Conclusively, industry-specific research are sparse, chiefly in the Nigerian context. However, the variables lack effective test despite its overwhelming influence. This study intends to fill this gap by investigating WCM and financial performance of quoted oil and gas firms in Nigeria for (5) years.

\subsection{Statement of the Problem}

When a firm lacks adequate working assets to insure its commitments due to inadequate WCM, fiscal insolvency can results to legitimate troubles, bankruptcy of resources and possible economic failure. An ineffective WCM system restrains the firm from either covering their fiscal obligations or increase their earnings.

Seeing the little per-capita proceeds and not reusable income of consumers, firms to clienteles, creating financial statement receivables. These firms from other firms, generating financial records receivables. The economy branded by low capability utilization of businesses, infrastructural collapse, unstable fiscal policies, non-existence of indigenous raw provisions inputs, unbalanced foreign conversation market, numerous taxation, of not reusable income and procuring power of populations, and has damagingly impacted on Nigerian firms.

Barine (2012) asserted that situations of firms are depressingly charged on bank lends obtained to meet instant financial compulsions, also imposed by abortive trade fiscal policies to clients. Multiple taxes have deteriorated the fiscal situations of firms. Fresh materials contributions, mostly trade in, are exaggerated by 
unhinged exchange. Raw register are thus exaggerated by scarce foreign conversation for import, delays in clearance at the port, and unfortunate transportation system. These disturb the manufacture runs of firms and conveyance to customers.

The 2013 Working Capital Performance Report by Ernst and Young (Nigeria) revealed that the working capital (WC) performance in 2013 deteriorated significantly. The report highlighted most Oil and gas companies focused less prior to 2013. Hence emphasis is gradually focused on rigorous cash and in an effort to boost their proceeds on investment and convey cover reserves and bonuses.

\subsection{Purpose of the study}

The working capital management on the financial performance of oil and gas firms in Nigeria is the study's purpose. The specifics include:

1. Ascertain the impact of Investing Policy on Assets of quoted companies in Nigeria

2. Evaluate the Financing Policy impact on the Return on Equity of quoted companies in Nigeria

3. Evaluate Investing Policy impact on the Earnings of quoted companies in Nigeria

4. Evaluate the impact of Financing Policy on the Earnings per share of quoted oil and gas companies in Nigeria

\subsection{Research Question}

1. To what degree does Investing Policy influence the ROA of quoted oil as well as gas corporations in Nigeria?

2. To what extent does Financing Policy influence the Return on Equity of quoted oil and gas companies in Nigeria?

3. To what degree does Investing Policy influence the Earnings per share of quoted oil as well as gas corporations in Nigeria?

4. To what degree does Financing Policy influence the Earnings per share of quoted oil in addition to gas companies in Nigeria?

\subsection{Study Hypothesis}

Ho: $\quad$ Investing Policy lacks significant influence on ROA of quoted oil and gas corporations in Nigeria.

$\mathrm{Ho}_{2}$ : Financing Policy lacks significant influence on the ROE of quoted oil and gas corporations in Nigeria.

Ho $_{3}$ : Investing Policy lacks significant influence on EPS of quoted oil and gas corporations in Nigeria.

Ho Ho $_{4} \quad$ Financing Policy lacks significant influence on the EPSof quoted oil and gas corporations in Nigeria.

\subsection{The Study Significance}

Theoretically: Very few studies have been made in Working Capital Management (WCM) especially in Nigeria. Therefore, the study is a maiden attempt to analyze working capital management (WCM) and financial performance (FP)in in Nigeria.

Practical Significance: This study investigates the work and financial relationship between quoted oil and gas companies in Nigeria. Generally, it is expected that managers of companies will benefit from the outcome of the study in the area of improving their companies performance.

The study's coverage: The Agency; Trade-off, Fisher's separation and cash conversion made up the study's theories. The study covers all sectors in Nigeria involved in gas and oil activities.

\section{Overview}

\section{Review Of Related Literature}

The section covers experiential review on WCM and how it affects performance financially.

\subsection{Theoretical Framework}

The Agency, Trade-off, Fisher's separation and cash conversion cycle theories will be employed in explaining existing relationships.

\subsubsection{Agency Theory}

An important factor that can influence the decision emanating as a possible divergence of interest between shareholders (principals) and managers (agents) of firms. The setting aside of contemporary business world brings about conflicts of interest between discipline instruments on management values.

Another agency problem source is the presence of free excess, stated by Jensen (1986) which is beyond that required for financing projects of value. 


\subsubsection{Trade-off Theory}

Generally, the trade-off theory refers to the idea that a corporations elects how considerable debt investment and how considerable equity funding to use by harmonizing the costs and paybacks. An imperative determination of the philosophy is to clarify that businesses usually are funded moderately with debt and partially with equity.

\subsubsection{Separation Theory}

Fisher Separation Theorem states that in the manifestation of perfect capital markets, the consumer's investment and consumption decisions are independent. All consumers invest along their capital project frontiers to the point where $r=i$, and then borrow or save to satisfy their particular personal rate of time preference. The Theorem has chief implications:

1. All investment opportunities are exploited.

2. All investment opportunities are priced the same, that is, priced by the same condition, $r=i$.

3. Efficient management of investment projects is achieved by maximizing investment.

In theory, firms should avoid confusion between the investment. This theory has to do with working capital because a firm should always separate how much they invest in working capital versus how much they will finance the capital.

\subsubsection{Cash Conversion Cycle Theory}

The money alteration cycle, embodies the communication amid the mechanisms of working principal and cash flowing within a firm, is employed to regulate the moneys wanted for any auctions level. Gitman (1974) established money conversion series as functioning sequence which is designed by adding account to books receivables dated and withdrawing accounts from it.

\subsection{Functioning/Conceptual Context \\ 2.2.1 Working Capital}

The 'Functioning Capital' is easily described, as capitals required for executing daily procedures of the industry effortlessly. The organisation of the waged capital is correspondingly imperative as the organization of continuing financial venture. Every consecutively business desires working money. Even a trade fully furnished with all fixed resources required is sure to ruin without

1. sufficient supply of resources for dispensation;

2. cash to reimbursement for salaries, power and other charges;

3. creating a routine of complete goods to nourish the marketplace demand frequently; and,

4. the skill to give credit to consumers. All require waged capital.

Operational capital is like the vital spark of a trade. The industry can't carry on everyday activities deprived of the adequate functioning capital.

\section{Classification of Functioning Capital}

Pandey (2004) elucidated that there are two notions of functioning capital. They include:

\section{Conceptual Classification}

Two theory of functioning capital exist viz., measurable and non-measurable. The measurable concept views the existing resources while other views the surplus of current resources over recent liabilities. Shortfall of functioning capital happens where the sum of present liabilities surpasses the total of existing assets.

\section{Financing Working Capital}

Now let us understand what it means to funding operational capital. Functioning money are those resources, which nothing like fixed resources alter their forms quickly. Owing to this environment, they get funded through immediate funds. Temporary assets are called existing liabilities.

\section{Excessive Functioning Capital}

Some of the dangers associated with Excessive Working Capital include:

1. Heavy asset in fixed resources - An anxiety may capitalise heavily in its stationary resources lacking justification by genuine sales. This may generate condition of over investment.

2. Reckless acquisition of resources- Inventory is acquired recklessly which fallouts in undeveloped slow stirring and obsolete record.

3. Speculative leanings - Speculative predispositions may rise and if turnover is amplified dividend circulation will also escalate. 


\section{Paucity of Functioning Principal}

1. Approximately the dangers associated with paucity of Functioning Capital comprise the subsequent

2. Execution of operational plans grow into difficult concern by achieving its income target.

3. It is problematic to pay bonus due to nonexistence of resources.

\section{Control of Functioning Capital}

Functioning capital prerequisite depends upon the flat process and span of functioning cycle. Observing the extent of operating sequence is key ingredient of functioning capital mechanism.

\section{Sufficiency of Operational Capital}

The significance of competent working principal can barely be described. John L. O. Milton and Donald S. Gladberg observe "Countless times corporate failure happens due to deficiency of functioning principal" (O'Donnell et al 1990). Working principal is considered the regulatory nerve hub of a trade. Inadequate functioning capital is trade disorder (Keens, 1950). Meaning a business has to uphold a sound functioning capital.

Source of Operational Capital: Orthodox generalizations concerning financing of operational capital propose that amount equivalent to the elementary least of existing assets ought be supported from long-standing source and seasonal requirements of operational capital be funded from temporary foundations (Osborn, 1969). It is understandable that arrangement aids in keeping cost of operational capital investment to the least for an initiative and reoccurrence on the entire funds hired.

Inventory: Inventory is key piece of existing assets. The organization of accounts - raw commodities, goods-inprocess and completed things is a vital issue in short-run liquescency positions and long-standing profitability of the corporation.

Raw goods inventories: Doubts about the imminent demand for complete goods, composed with cost of regulating production to modify demand will bring about a monetary manager to craving some equal of raw goods inventory.

Work-in-process inventory: This record is constructed up in production sequence. Production sequence is the duration between outline of fresh material into manufacture and development of done product at accomplishment of manufacture cycle.

Finished merchandises inventory: Completed goods are required for aims similar to causing the establishment hold fresh materials records. Customer's request for completed goods is indeterminate and inconstant. If a business lacks completed goods record, unanticipated upsurges in demand can require unexpected increases in the proportion of manufacture to encounter the request. Such speedy rise in the frequency of manufacture is very luxurious to achieve.

\section{Goals of Record Management}

1. To curtail idle charge of machineries caused by scarcity of raw constituents, stores and replacement parts.

2. To preserve down:

a. Record ordering charge.

b. Inventory transport cost,

c. Assets savings in records.

d. Obsolescence damages

\section{Receivables}

Countless firms brand credit auctions and as an upshot carry a current benefit. The drill of transporting receivables has numerous benefits which comprise:

1. decrease of gathering costs above cash assemblage,

2. Decrease in the inconsistency of transactions, and

3. upsurge in near-term transactions.

Money and interest-bearing assets: Money is the utmost tools of commonplace operation, since it is a procedure of handy capital that is accessible for task to any usage. Money is frequently the key factor deciding the sequence of trade destiny. The choice to enlarge a trade may be strong minded by the handiness of money and appropriating of assets will regularly be verbalized by money position. 
Methods of operational capital breakdown

Various motives may mark it indispensable to scrutinize the operational capital location of a trade enterprise. A reason for examining the operational capital location of a firm is for determination of fiscal statements examination.

\section{Funds Movement Analysis of Operational Investment}

This examination shows how assets have been acquired for a trade and their usage. This method helps to scrutinise changes in operational capital machineries amongst two records.

\section{Ratio Examination of Operational Capital}

It is the best commonly employed technique dealing practically in every feature of operational capital investigation. In this procedure, each feature of scrutiny contains ratios calculated and results drawn on trends basis showing those stationary as monitor- posts.

\subsubsection{Operational Capital Administration}

Operational capital administration is an imperative feature of financial running. It is the essence and governing nerve midpoint for any types of business organization because without the proper control of it, no business can run smoothly (Joshi, 2013). The administration of existing assets and present liabilities is essential for daily operations of any organizations. Thus, it plays the vital parts in the accomplishment and disappointment of the establishments as it contract with part of resources, which are transformed from one form to another of manufacturing cycle. Therefore, the part of operational capital running is extra significant for every business organization irrespective of their nature.

\section{Significance of Operational Capital Administration}

For suave running an initiative, adequate quantity of operational resources is very vital. Competence in this part can aid, to employ fixed resources gainfully, to guarantee the company's long- term achievement and to attain the complete goal of growth of the stockholders, fund. Deficiency of money may upshot in loss reduction of status due to defaulting of responsibility on payable dates.

\section{Importance of Operational Capital Administration}

Resources are necessary in every trade for transport on day-to-day tasks. Working resources are considered as the existence of a firm. It can occur and continue without constructing income but cannot continue without operational capital resources. If a Business is not making income it may be labelled 'sick', not having operational money may bring about bankruptcy operational money to persist.

\section{Principles of Operational Capital Administration}

The succeeding are the values of operational capital administration:

- Principles of hazard variation

- Value of fairness position

- Value of cost capital

- Value of development payment

\section{Functioning Cycle}

The length required for the subsequent sequence of proceedings, in situation of industrialized firm, is named the functioning cycle:

1. Adaptation of moneys into fresh products.

2. Alteration of raw resources into progressive work

3. Transformation of effort in progression into completed goods.

\section{Length of the Operational Cycle}

The length of the functioning cycle is equivalent to the sum of the extent of these phases less the praise period allowable by the dealers of the business. In signs,

$\mathrm{O}=\mathrm{R}+\mathrm{W}+\mathrm{F}+\mathrm{D}-\mathrm{C}$

As,

$\mathrm{O}=$ period of functioning cycle.

$\mathrm{R}=$ fresh material packing period.

$\mathrm{W}=$ Period of work-in-progress.

$\mathrm{F}=$ completed goods loading period.

$\mathrm{D}=$ borrowers collection time, and

$\mathrm{C}=$ borrowers payment time. 
Factors that Influence Operational Capital Administration

Factors that influence operational capital administration are:

- Environment of the Trade

- Deals and Request Conditions

- Know-how and Industrial Policy

- Credit Rule

- Accessibility of Credit

- Functioning Efficiency

- Worth Level Variations

\section{Components of Operational Capital Administration}

- Inventory Organisation

- Finance receivables

- Cash

- Finance payables

\subsubsection{Investing Policy}

This reflects the affiliation between full current resources and full resources which reveals the hostility of the individual's aggressive venture rule (Nazir\&Afza, 2009; Vahid, Mohsen \& Mohammadreza, 2012). In additional words, a subordinate ratio specifies a moderately aggressive asset strategy by the object. Current resources investment strategy is the percentage of venture in recent assets and stationary assets (Mohan and Alok, 2001).

\subsubsection{Financing Policy}

This reflects the association between whole current charges and total assets which reflects the assertiveness of the entity's forceful financing strategy (Nazir\& Afza,2009; Vahid, Mohsen \& Mohammadreza, 2012). In other words, advanced ratio designates a relatively advanced aggressive funding policy by the entity. There are dissimilar approaches to take this decision linking to funding mix of the operational capital as follows:

\section{Aggressive Approach}

A Business concern may be destructive in funding its current resources. A destructive policy may be tailed by the trade concern when it employs more small term bases of funding as a major portion of its lasting current resources.

\section{Hedging or Matching Approach}

A business firm may follow a financing plan which is founded on the belief of matching. It implies short term needs and financing long term requirement. Haley and Schall (1977) observe regarding "the idea expressed in this principle is to match the maturity of the funds of the lengths."If the accurate matching is possible, the strategy operates without any since all short term requirements are funds.

\section{Conservative Approach}

A firm may trail a traditionalist approach to economics its current resources. A firm rest on the long term foundations of funds for funding its requirements. The firm relies more on its needs and small term funds are only to emergency situation.

\subsubsection{Financial Performance}

The word 'Presentation is resultant from the word 'parfourmen', which means 'carry out'. It speak of performing; execution, accomplishment, fulfilment, etc. In border intellect, performance denotes triumph of a given chore measured alongside preset values of correctness, completeness, price, and speed.

\section{Financial Performance Analysis}

Financial forecasters often evaluate firm's creation and efficiency performance, productivity performance, WCP, fixed resources performance, and societal performance. The parts of fiscal performance evaluations include:

1. Working assets Analysis

2. Fiscal structure Examination

3. Activity Analysis

4. Profitability Analysis 


\section{Significance of Fiscal Performance Investigation}

Interest of numerous related clusters is exaggerated by the fiscal performance of an entity. Therefore, these groups analyze the fiscal performance of a corporation. The kind of scrutiny varies giving to the exact interest of parties involved.

1. Trade creditors: concerned in the firms liquidity

2. Bond holders: concerned in the cash-flow capacity of the firm

3. Investors: concerned in present-day and expected yet to come in comes and stability of incomes

4. Management: concerned in interior control, better fiscal condition and improved performance

\subsubsection{Return on Assets- ROA}

ROA is a fiscal proportion showing fraction of company receives relating to its general resources. Net pay is the revenue after levies. Companies acquired a grouping called "good will" representative of further money remunerated over and beyond its genuine book worth at time of procurement. Because assetsfluctuates over while, an ordinary assets above the era to be measured is used. Consequently the return for a section should be built on net revenue for the quarter divided by normal assets in that quarter. It is a proportion but frequently presented as a fraction.

\section{Uses of ROA}

Contrasting productivity proportions, like (ROE), ROA dimensions include all industry's assetspersons which ascend out of charges to creditors and resources remunerated in by stockholders. Total resources are used relatively than remaining assets. Consequently, for illustration, the currency holdings of a firm have been hired and are accordingly balanced by a responsibility. Likewise, the firm's receivables are unquestionably an advantage but are well-adjusted by its payables, a responsibility.

\subsubsection{Earnings per Share}

Earnings per share is planned to indicate each shareholder's proportionate company's earnings share. An utter increase in remaining revenue is not, an ample indicator as net earnings may upshot to increased investment. For illustration, a firm may subject more shares for money. This is earnings dilution example. Since EPS statistics are so extensively employed in fiscal community, and establishments might calculate EPS figures differently, accounting standard setters in many countries for computation of EPS.

\section{Basic Remunerations per Segment}

An individual shall compute basic remunerations per segment amounts for turnover attributable to regular equity containers of the parental body and, if accessible, profit or damage from remaining procedures attributable to those even-handedness holders.

\section{Diluted Remunerations per Segment}

A body shall calculate diluted remunerations per Segment amounts for turnover attributable to normal equity containers of the parental entity and, if offered, profit or forfeiture from ongoing processes attributable to those even-handedness holders.

For the determination of computing diluted remunerations per Segment, an entity will adjust turnover or forfeiture attributable to normal equity containers of the parental entity, and weighted normal number of dividends unresolved, for the properties of all dilutive possible ordinary portions.

\subsubsection{Return on Equity}

$\mathrm{ROE}$ is the measure of net earnings reimbursed as a proportion of stockholders equity. It reveals a corporation equity found on taking a year's worth of earnings and dividing them by the average shareholder equity for that year.

ROE $=$ Net income after tax / Shareholder's equity

\subsection{Empirical Appraisal}

Preceding studies testified that operational capital administration has an imperative consequence on the administration's financial routine. Shin and Soenen (1998), Lazaridis and Tryfonidis (2006), Raheman and Nasr (2007), amongst others, computed working assets with money translation cycle, which entails stockholding era, debtors' assemblage era and creditors' reimbursement era. These academics supported that superior investment in operational capital tops to decrease in the administration's productivity (Banos-Caballero et al, 2010, and Nazir and Afza, 2003, 2009). Deloof (2003) employed a trial of Belgian establishments and established that establishments can upsurge their productivity by dropping the debtor's collection era and days-in-inventory era. He similarly established that less gainful organizations wait lengthier to wage their employees and bills. Wang 
(2002) employed a model of Japanese in adding to Taiwanese establishments and established that a smaller cash transformation cycle would top a healthier establishment's working performance. The association between WCM and fiscal performance is additional evaluated through four working hypotheses. They include:

Ho: $\quad$ Investing Policy has no significant effect on the Return on Assets of quoted oil and gas companies in Nigeria.

$\mathrm{Ho}_{2}$ : $\quad$ Financing Policy has no significant effect on the Return on Equity of quoted oil and gas companies in Nigeria.

Ho $_{3}$ : Investing Policy has no significant effect on the Earnings per share of quoted oil and gas companies in Nigeria.

Ho : Financing Policy has no significant effect on the Earnings per share of quoted oil and gas companies in Nigeria.

\section{Overview}

\section{Research Method}

This section presents the study approaches that the scholar adapted to facilitate carrying out of the enquiry to satisfy education objectives. Rudiments of the school work methods include:

\subsection{Study Design}

Study design is the strategy and arrangement of investigation so considered as to get answers to study questions. The strategy is the all-purpose scheme of the investigation (Robson, 2002). The cross sectional of the quasi-experimental investigation design is the enquiry design accepted in this study. It was chosen as it targets to study the association of the objects in the education populace (Baridam, 2001).

\subsection{The Study's Populace}

The populace of attention in this schoolwork constitutes all corporations engaged in the oil as well as gas segments based on the grouping of the stock conversation of Nigeria (NSE). They include 14 sub-sectors of the oil as well as gas quoted on the NSE as at 31-12-2014. The 2014 fiscal year was accepted because this schoolwork covers an era of 5 years with 2010 representing the base year.

\subsection{Techniques for sampling and choosing Sample}

Eleven (11) of the mentioned oil in addition to gas establishments were nominated for the school work covering the earmarked period. The eleven corporations were branded by the accessibility of all essential facts for the measurable computation of operational capital administration for the appropriate years.

\section{Table 3.1 Population and Study Sample}

The details about the establishment of the sectors investigated in the current study was gotten from the NSE Cumulative Databank of 2015.

\subsection{Operational Procedures of Variables}

Working Capital Management (WCM) and the accepted dimensions are:

- Financing Policy (FP): $\quad$ Total Present Liabilities

- $\quad$ Investing Policy (IP): Total Assets

Total Present Resources

Aggregate Assets

\subsection{Validity and Consistency of the Instrument}

The study used secondary sources from the Financial Database of 2015 from quoted companies of the NSE. These accounts are appraised and validated hence no necessity for soundness and consistency tests.

\subsection{Model Stipulations}

The purposeful and functioning relationship of the principle and predictor tools of the schoolwork is communicated below:

$\begin{array}{lll}\text { FP } & = & \mathrm{f}(\mathrm{WCM}) \\ \mathrm{WCM} & = & (\mathrm{INVP}, \mathrm{FINP}) \\ \mathrm{FP} & = & (\text { ROA, EPS, ROE) } \\ \text { Where, } & & \\ \text { FP } & = & \text { Financial Performance } \\ \text { WCM } & = & \text { Working Capital Management } \\ \text { INVP } & = & \text { Investing Policy }\end{array}$




$\begin{array}{lll}\text { FINP } & = & \text { Financing Policy } \\ \text { ROA } & = & \text { Return on asset } \\ \text { EPS } & = & \text { Earnings per Share } \\ \text { ROE } & = & \text { Return on Equity }\end{array}$

The prototype shows the collaborating relationships amongst the benchmark and forecaster variables.

\subsection{Data Analysis Methods}

The regression prototype specification was employed to evaluate the associations between items, and inspect how fluctuations in stages of $\mathrm{X}$ (forecaster variable) communicate to modification in heights of $\mathrm{Y}$ (standard variable) (Baridam, 2001). The standards for computations was employed using the t-test since the numbers are beneath 30. The constant of correlation is signified as $r$. The research adopted the usage of type 22.0 of the SPSS to examine the hypotheses.

\section{Presentation and Analysis of data}

This section analysed the information gotten and offered based on appropriate techniques for this study. The studies were completed employing PPMC and analysis of the regression through SPSS version 22.0. Also, the Simple Linear Regression was conducted and results obtained.

\section{Table 4.1 Expressive Statistics (see the appendix section)}

Table 4.1 highpoints the outcome of the expressive data of the summations and normal deviance for substitutions of WCM and Fiscal Performance adopted. The Table 4.1 additionally discloses that Investing Policy has a mean of 0.57447 and normal deviation of 1.269052. In addition, Investing Policy data range from a concentrated numeral of 10.000 to a tiniest of 0.008 . In addition, Financing Policy has a significance of 0.60225 and standard deviance of 1.072981 with extreme and smallest figures of 8.297 and 0.063 respectively. The expressive statistics more exposed that ROA with mean of 0.45145 and standard deviance of 3.644511 . Additionally, EPS has a mean charge of 1.36110 and a normal deviation of 8.275467 with concentrated and tiniest figures of 17.730 and -46.000 respectively.

\subsection{Data Analysis}

The PPMC result analysis between Investing Policy as depicted in Table 4.2.1 (see the appendix). This result implies that optimum Investing Policy will definitely increase Assets of multinationals in oil sub-sector. In addition, poor investing policy will leads to fall in ROA of the units.

\section{Table 4.2.2}

The PPMC environment between investing policy and incomes per share as 4.2.2 shows investing policy and this result signifies that earnings per share cannot be influenced by the investing policy of quoted oil companies in Nigeria.

\section{Table 4.2.3}

It discovered that correlation shows an undesirable and insignificant association and reoccurrence on equity with a coefficient of -0.024 . This result indicates that return on equity cannot be influenced by the investing policy of quoted oil companies in Nigeria.

\section{Table 4.2.4}

**. Correlation is substantial at the 0.01 stage (2-tailed).

The upshot of PPMC examination between Financing Policy and Return on Assets as presented in Table4.2.4 publicized a constructive and perfectly significant connection between both and a constant of 0.932 . This result implies that optimum Financing Policy will definitely upsurge the Reoccurrence of Assets of firms in the oil sub-sector. In addition, poor financing policy will lead to a fall in the Return on Assets of the research units.

\section{Table 4.2.5}

The PPMC environment between financing policy and earnings per share as displayed in Table4.2.5 is encouraging but inconsequential relationship amid financing policy and earnings per share with a constant of 0.019 . This result signifies that earnings per share cannot be influenced by the financing policy of quoted oil companies in Nigeria. 
Table 4.2.6

**. Correlation is significant at the 0.01 level (2-tailed).

Table 4.2.6 revealed that correlation and inconsequential relationship exists on equity with a number of -0.032. This result illustrates that ROA cannot be influenced by the investing policy of quoted oil corporations in Nigeria.

\section{Regression Scrutiny}

Table 4.2.7

a. Predictors: (Constant), INVTPLCY

The regression breakdown as understood in table 4.2.7 exploited investing strategy as the clarifying variable and ROA as the answer variable. It discloses that the relationship constant (R) specifies a strong result of .973 and coefficient of purpose indicates that $94.7 \%$ of the alteration in ROA can be clarified by the financing policy of oil enterprises in Nigeria. Conclusively, associating the t-value of 32.038 to the p-value of 0.000 designates that the constants are statistically substantial.

\section{Table 4.2.8}

The regression utilized investing policy and incomes per segment as the reply variable. It discloses coefficient (R) designates a dismal outcome of .020 whereas the constant of purpose designates that $0.01 \%$ of the modification in incomes per segment by the capitalising strategy of oil corporations in Nigeria. Conclusively, likening the t-value of 0.149 to the p-value of 0.882 designates that the constants are statistically immaterial.

\section{Table 4.2.9}

The regression analysis as seen in table 4.2.9 utilized investing policy as the descriptive variable and ROE as the reply variable. The table discloses that the connection constant $(\mathrm{R})$ designates a poor outcome of .024 whereas the constant of purpose designates that $0.1 \%$ of the alteration in ROE can be clarified by the capitalizing strategy of oil enterprises in Nigeria.

\section{Table 4.2.10}

The regression analysis as seen in table 4.2.10 utilized financing policy as the explanatory variable with result of .932 while the coefficient of determination indicates that $87 \%$ of financing policy of Nigeria. Additionally, the F-statistics reveals the strength of the model as its worth of 386.489 is more than 0.000 . Conclusively, likening the t-value of 19.659 to the p-value of 0.000 designates that the constants are statistically important.

\section{Table 4.2.11}

The regression analysis as seen in table 4.2.11 utilized financing policy as the descriptive variable and pays per share as the reaction variable. It discloses that the link coefficient (R) signposts a poor outcome of .019 while the constant of purpose designates that $0.01 \%$ of the modification in pays per segment can be clarified by the dogma of oil establishments. Moreover, this illustrates that $99.99 \%$ of fluctuations in pays per segment are accounted for by supplementary factors exterior the model.

\section{Table 4.2.12}

The regression analysis as seen in table 4.2 .12 utilized financing policy with result of .032 while constant of purpose indicates that $0.1 \%$ of the modification in reoccurrence on equity can be clarified by the financing policy of oil establishments. Furthermore, this shows that $99.9 \%$ of variations in reoccurrence on equity are accounted for by features separate from the model. In totalling, the F-statistics dismissed the cogency of the prototype as its worth of 0.059 is less than its sig worth of 0.809 . Conclusively, comparing the t-worth of -0.243 to the p-worth of 0.809 indicates that the coefficients are statistically insignificant.

\subsection{Discussion of Findings}

The work examined working capital management on financial presentation of oil establishments in Nigeria. The suppositions of the work were verified with the staging of the Regression Break down employing SPSS version 22.0. The research empirically tried six hypotheses. The conversation of discoveries is as follows:

\section{Relationship between investing policy (IP) and ROA}

$\mathrm{HO}_{1}$ : Investing Policy has no significant effect on the Return on Assets of quoted oil and gas companies in Nigeria. 
The discoveries reveals that investing policy and ROA are definitely and perfectly related. Therefore, while the clarification variable is significantly is more than $50 \%$, it means the model is fit and good. Also, as of the assessment of proposition using the PPMCC, a significance of .973 was grasped to designate a flawless and constructive correlation.

\section{Relationship between funding policy (FP) and ROE}

$\mathrm{HO}_{2}$ : Financing Policy has no significant effect on the Return on Equity of quoted oil and gas companies in Nigeria.

The outcome of the regression breakdown displays that Financing policy and ROA are negatively related (see tables 4.2.7 and 4.2.12). Therefore, since the explanation variable is less than 50\%, it shows that the model does not have a good fit. Also, from the test of hypothesis using the Pearson's Product Moment Correlation coefficient, a value of 0.032 was gotten. Thus, the null hypothesis is accepted, while the alternative hypothesis is rejected.

\section{Relationship between investing policy (IP) and EPS}

$\mathbf{H O}_{3}$ : Investing Policy has no significant effect on the Earnings per share of quoted oil and gas companies in Nigeria.

The outcome of the regression breakdown shows that capitalizing policy and EPS are positively linked (see tables 4.2.2 and 4.2.8). Ngunan (2011) who studied WCM and regression technique to analyse firms. The findings revealed no significant connection between WCM and earnings per share.

\section{Relationship between funding policy (FP) and earnings per share (EPS)}

$\mathbf{H O}_{4}$ : Financing Policy has no significant effect on the Earnings per share of quoted oil and gas companies in Nigeria.

Also, from the test of hypothesis using the Pearson's Product Moment Correlation coefficient, a value of 0.019 was realized to indicate no correlation. Thus, the null hypothesis is accepted, while the alternative hypothesis is rejected.

\subsection{Summary}

\section{Summary, Conclusion and Recommendations}

The research involved the supposition of hypotheses for applicable statistics were gotten from the Nigerian Stock Exchange Aggregate Database of 2015. Following to the study, it was detected from the study that of four propositions tested, only return on assets was positively and significantly predisposed by proportions of WCM.

\subsection{Conclusion}

Conclusively, the study and research of the influence of working capital management on the fiscal performance (reply variable) of oil and gas companies quoted in the Nigerian Stock Exchange for 5 years ended December, 2014.

The conclusions are:

1. Investing Policy has a significant consequence on the Reoccurrence on Assets of quoted oil in addition to gas corporations in Nigeria.

2. Financing Policy has no significant effect on the Return on Equity of quoted oil and gas companies in Nigeria.

3. Investing Policy has no significant effect on the Earnings per share of quoted oil and gas companies in Nigeria.

4. Financing Policy has no significant effect on the Earnings per share of quoted oil and gas companies in Nigeria.

\subsection{Recommendations}

Getting to the discoveries of the research, the subsequent are hereby recommended:

1. Corporations in the oil in addition to gas segment should carry out comprehensive appraisal of their financial performance trend and their WCM framework. These will allow the companies design effective action plans achieve goal of performance maximization.

2. Companies in the sector should establish adequate benchmarks of working capital components in order for emerging obligations to be met adequately

3. Regulatory authorities and the administration should offer a sound business atmosphere in terms of business-friendly regulations, adequate infrastructural facilities, security, etc. these will enhance the presentation of business organizations in a state, especially target firms for their strategic importance to the Nigerian Economy. 


\subsection{Support to Information}

This work has added to the current pool of information on working capital management especially in Nigeria as appreciable works on the variances in the Nigerian monetary setting. In addition, this work adds to the widely acclaimed literature on WCM by esteemed scholars namely Nazir \&Afza (2009) in addition to Deloof (2003). Additionally, the prototypes hypothesized for the drive of this study are another form of knowledge contribution. The models highlight the connection between WCM and fiscal performance. The models are set as:
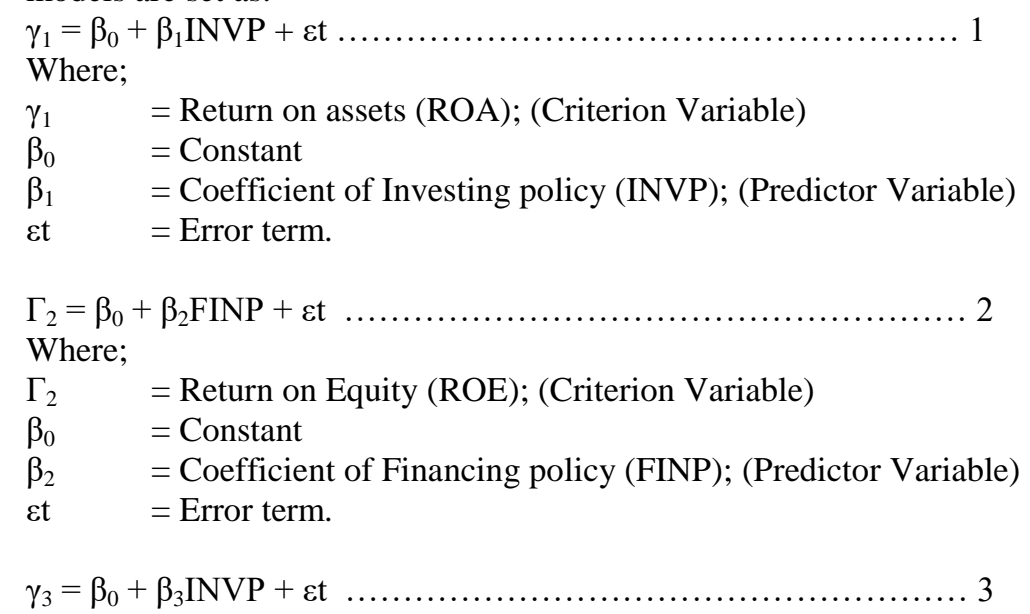

Where;

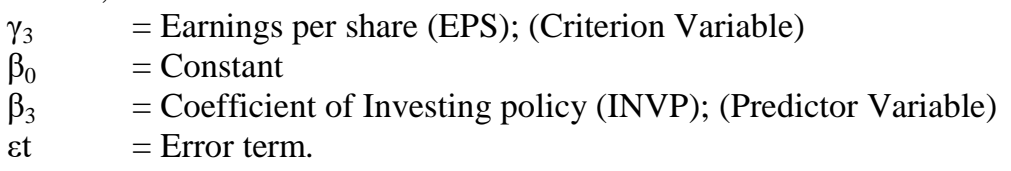

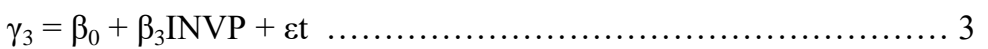

Where;

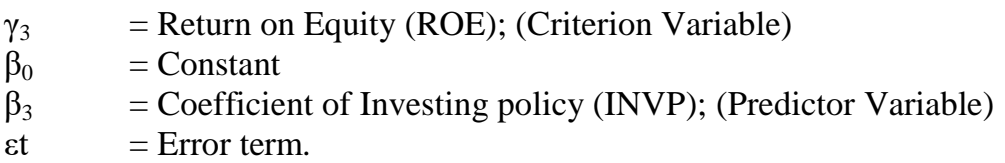

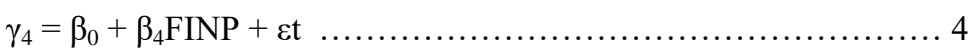

Where;

$\gamma_{4} \quad=$ Earnings per share (EPS); (Criterion Variable)

$\beta_{0} \quad=$ Constant

$\beta_{4} \quad=$ Coefficient of Financing policy (FINP); (Predictor Variable)

et $\quad=$ Error term.

\subsection{Policy Inference}

The investigation, results and discoveries from this study have inferences for law makers particularly for the Panel of Managements of oil in addition to gas firms in Nigeria. The key implication is that if administration is not effective, especially in terms of investing the firm will be adversely affected and the continuity of the firm will be threatened in the long run.

\subsection{Limitation of the Research}

The decision of this research to hinge the investigation of WCM on Investing and funding policies may be less fancied by other researchers who prefer other dimensions like conversion sequence, inventory transformation period and debtors' collection period. Additionally, the study relies on advanced data obtained from final accounts of oil and gas corporations quoted in the Nigerian Stock Exchange.

\subsection{Propositions for Additional Studies}

The discoveries revealed that, there lacks significant association between investing policies and both EPS and ROE. Further results also showed an inconsequential relationship amongst financing policy and both EPS and ROE. Nature of capital, fiscal leverage, firm size and technological changes may apply a bigger effect on the performance procedures, which were not considered in this study. Hence, there is a robust need for 
additional empirical researches that can classify the issues that regulate the fiscal performance of oil and gas corporations in Nigeria particularly in EPS and ROE.

\section{References}

[1]. Adediran A. S., Josiah M., Bosun-Fakunle Y. and Imuzeze O. E. (2012). The Impact of Working Capital Management on the Profitability of Small and Medium Scale Enterprises in Nigeria. Research Journal of Business Management, 6: pp 61-69.

[2]. Aloy J. Niresh (2012). Working Capital Management \& Financial Performance of Manufacturing Sector in Sri Lanka.European Journal of Business and Management www.iiste.org.ISSN 2222-1905 (Paper) ISSN 2222-2839 (Online). 4-15,

[3]. Anyanwu, A. (2000). Research Methodology in Business and Social Sciences, Owerri, Nigeria.Canun Publishers, Nig. Ltd.

[4]. Arnold, G. (2008). Corporate Financial Management.4th edition.Prentice Hall. Essex.

[5]. Banos-Caballero S, P. Garcia-Teruel and P. Martinez-Solano (2010), Accounting and Finance, Vol 50, pp. 511-527.

[6]. Baridam, D. M. (2001).Research Methods in Administrative Sciences (3rd edition), Port Harcourt, Nigeria. Sherbrooke Associates.

[7]. Barine, M. N. (2012). Working capital management efficiency and corporate profitability: Evidence from quoted firms in Nigeria. Journal of Applied Banking and Finance, 2(2) 1792-6580.

[8]. Bhunia, A. \& Das, A. (2012).Affiliation between Working Capital Management and Profitability.Interdisciplinary Journal of contemporary research in business, 3(9), 957-968

[9]. Block, S. B., Hirk, G. A., \& Short, J. D. (2000). Fundamentals of Financial Management. New Delhi: Dow Jones and Company Chicopee.

[10]. Brigham, E. F., \& Houston, J. F. (2002).Fundamentals of financial management. (9th ed.). New York. Harcourt College.

[11]. Brigham, E., \&Gapenski, L. (1997).Financial Management Theory and Practice (8th Ed.). Fort Worth TX. The Dryden Press.

[12]. Chung, R; Firth, M; Kim, J. (2005). FCF agency cost, earnings management, and investor monitoring. Corporate Ownership and Control, Vol 2, pp. 4

[13]. D.K. Lindo (2008). Asset Management is Your Job, in Super Vision, vol. 69, issue 1, pp. 14-18.

[14]. D.L. Thomas Keens (1950) Business Accounts and How to Real them in Studies in Accounting, (New York: W.T. Baxter, Sweet and Maxwell Ltd.), pp.88

[15]. De Vaus, D.A. (2001).Research Design in Social Research. London: SAGE

[16]. Deloof, M. (2003). Does working capital management affect profitability of Belgian firms? Journal of Business Finance \& Accounting, 30 (3-4), pp. 573-588.

[17]. Dolandson E.F. (1956). Corporate Finance, New York, Ronald Press Company, pp. 479.

[18]. Dong, H. P., \& Su, J. T. (2010). The Relationship between Working Capital Management and Profitability: A Vietnam Case. International Research Journal of Finance and Economics, 49(1), pp. 59-67.

[19]. Gitman, L.J. (1974), Estimating Corporate Liquidity Requirements: A Simplified Approach, The Financial Review, Vol. 9, pp. 7988.

[20]. Hassan N.,Imran M.M, Amjad M and Hussain M. (2014). Effects of Working Capital Management on Firm Performance: An Empirical Study of Non-financial listed Firms in Pakistan. International Journal of Academic Research in Business and Social Sciences, 4-6 ISSN: 2222-6990

[21]. Horngren, C. T., Datar, S. M., \& Foster, G. (2003). Cost accounting 11th ed. India. Dorling Kindersley Private Ltd. Journal of Business Finance \& Accounting, (3\&4), pp 573-587.

[22]. Hutchinson, P.D., Farris II, M.T., \& Andres, S.B. (2007).Cash-to-Cash analysis and Management.The CPA Journal, 77 (8), $42-47$.

[23]. IbeajaUzoma (2012). Business Research Methods, Vol 1.Millennium Publications, Owerri.

[24]. Jensen M. (1986). Agency Costs of Free Cash Flow, Corporate Finance and Takeovers,AmericanEconomic Review, 76(2): $323-329$.

[25]. Jensen M.,Meckling W. (1976). Theory of the Firm: Managerial Behavior, Agency Costs and Ownership Structure, Journal of Financial Economics, Vol 3, pp 305-360.

[26]. Jose, M. L., Lancaster, C. \& Stevens, J. L. (1996). Corporate Returns and Cash Conversion cycles, Journal of Economics and Finance, 20, Vol 1, pp 33-46.

[27]. Joshi, R. (2013). Working Capital Management of Commercial Banks in Nepal: Being anM.sc. Thesis submitted to faculty of management Tribhuvan University, Shankar Dev. Campus, Kathmadu.

[28]. K.V. Kulkarni (1983). Financial Management, New Delhi, Himalayan Publishing House, pp. 399.

[29]. Lawrence Imeokparia(2015).Working Capital Management and Performance of Food and Beverage Industry in Nigeria.Research Journal of Finance and Accounting. ISSN 2222-1697 (Paper) ISSN 2222-2847 (Online)Vol.6, No.16.

[30]. Lazaridis, I. and Tryfonidis, D. (2007). The Relationship between Working Capital Management and Profitability of Listed Companies in the Athens Stock Exchange, Journal of Financial Management andAnalysis, Vol. 19 No.1, pp. 26-35.

[31]. Lazaridis, I., and Tryfonidis, D. (2006).Relationship between working capital management and profitability of listed companies in the Athens stock exchange.Journal of Financial Management and Analysis 19(1), pp. 26-35.

[32]. Mathuva D.M. (2009). The Influence of Working Capital Management Components on Corporate Profitability: A Survey on Kenyan Listed Firms, Research Journal ofBusiness Management, www.docsdrive.com/pdfs/academicjournals/rjbm/0000 /1598815988.pdf

[33]. Merton, R. C. (1980). On Estimating the Expected Return on the Market: An Exploratory Investigation, Journal of Financial Economics, 8, pp. 323-361.

[34]. Mohan Rao P. and Alok Kumar Pramanik(2001).WorkingCapitalManagement,1stEdition,Deep\&DeepPublication,NewDelhi, pp.14.

[35]. Mugenda, M.O., and Mugenda, G.A. (2003).Research Methods: Quantitative and Qualitative Approaches. Laba Graphics Services.

[36]. Nazir M. and T. Afza, (2003). The focus of Working Capital Management in UK Small Firms, Managerial Accounting Research, Vol. 14.

[37]. Nazir M. and T. Afza, (2009).Impact of Aggressive Working Capital Management Policy on Firm's profitability, The IUP Journal of Applied Finance, Vol. 15.

[38]. O'Donnel and Milton S. Goldberge, (1990) Accountants Financial Administration, (New Delhi, Prentice Hall of India Private Ltd.), pp 55.

[39]. Ogundipe, S. E., Idowu, A. \&Ogundipe, L. O. (2012).Working capital management, firms' performance and market valuation in Nigeria.World Academy of Science, Engineering and Technology, 61, pp. $1196-1200$.

[40]. Omolade A. and Mukolu M.O. (2013).Working Capital and Organization Performance in Nigeria.International Journal of Business and Management Invention ISSN (Online): 2319 - 8028, ISSN (Print): 2319 - 801

[41]. Onwumere, J. U. J., Ibe I. G.,\&Ugbam O. C.(2012). The impact of working capital management on profitability of Nigerian Firms: A preliminary Investigation, European Journal of Business and Management, 4(15) 2222-2839. 
[42]. Osborn, C. Richard (1969) Corporation Finance, (New York: Harper \& Brothers, pp. 353 and 371

[43]. Owolabi, S. A.,\&Alu, C. N. (2012). Effective working capital management and profitability: A study of selected quoted manufacturing companies in Nigeria. Economic and Finance Review, 6(2057-0401), 55-67.

[44]. Padachi, K. (2006). Trends in Working Capital Management and its Impact on Firms' Performance: An Analysis of Mauritian Small Manufacturing Firms. International Review of Business Research Papers Vo.2 No. 2. pp. 45 -58

[45]. Pandey, I.M., (2004). Financial Management.8th Edition, Vikas Publication Limited, India.

[46]. Raheman, A. \&Mohamed ,N. (2007). Working Capital Management and Profitability Case of Pakistani firms.International Review of Business Research Paper,3(1), pp.279-300.

[47]. Raheman, A. and Nasr, M. (2007). Working Capital Management and Profitability - Case of Pakistani Firms, International Review of Business Research Papers, Vol. 3 No.1, pp. 279-300.

[48]. Rajesh, M., Reddy, (2011). Impact of working capital management on firms profitability. Global Journal of Finance and Management. Vol 3, N.1, pp.151-158.

[49]. Richards, V. D., \& Laughlin, E. J. (1980).A cash conversion cycle approach to liquidity analysis.Financial management, pp 32-38.

[50]. Robson,C. (2002). Real World Research.A Resource for Social Scientist and practitioners, Research Oxford Blackwell.

[51]. Schall L. D. and Haley C. W. (1977).Introduction to Financial Management, McGraw-Hill Book Company, New York, pp. 571.

[52]. Scott, J.D. Martin, J.W. Petty and A.J. Keown (1991).Basic Financial Management, 8th ed., Prentice Hall, New Jersey.

[53]. Sharma, A.K., \& Kumar, S. (2011). Effect of Working Capital Management on Firm Profitability: Empirical Evidence from India Global Business Review, 12(1), pp. 159 - 173.

[54]. Shin H.H. and L. Soenen (1998).Efficiency of Working Capital and Corporate Profitability.Financial Practice and Education, Vol. 8, pp. 37-45,.

[55]. Vahid,T.K. , Mohsen,A.K. \&Mohammadreza, E. (2012). The Impact of Working Capital Management Policies on Firm's Profitability and Value: Evidence from Iranian oompanies; International Research Journal of Finance

[56]. Velnampy, T., \&Niresh, J.A. (2012).The Relationship between Capital Structure and Profitability.Global Journal of Management and Business Research, 12(13), 40-75.

[57]. Wang, Y.J. (2002). Liquidity Management, Operating Performance, and Corporate Value: Evidence from Japan and Taiwan, Journal of Multinational Financial Management, Vol. 12, pp. 159-169.

[58]. Working Capital Performance Report 2013 by Ernst and Young (Nigeria) EYG no. DW0430 CSG/GSC2014/1433095

[59]. Yahaya A. and Bala H. (2015).Working Capital Management and Financial Performance of Deposit Money Banks in Nigeria. Research Journal of Finance and Accounting. ISSN 2222-1697 (Paper) ISSN 2222-2847 (Online) Vol.6, No.16.

\section{Appendices:}

Table 4.1 Expressive statistics

\begin{tabular}{|l|l|l|l|l|l|}
\hline & $\mathrm{N}$ & Minimum & Maximum & Mean & Std. Deviation \\
\hline INVTPLCY & 60 & .008 & 10.000 & .57447 & 1.269052 \\
\hline FINPLCY & 60 & .063 & 8.297 & .60225 & 1.072981 \\
\hline ROA & 60 & -1.267 & 28.158 & .45145 & 3.644511 \\
\hline EPS & 60 & -46.000 & 17.730 & 1.36110 & 8.275467 \\
\hline ROE & 60 & -37.720 & 47.832 & 7.88443 & 14.910545 \\
\hline Valid N (listwise) & 60 & & & & \\
\hline
\end{tabular}

Table 4.2.1

\begin{tabular}{|c|c|c|c|}
\hline \multicolumn{4}{|l|}{ Correlations } \\
\hline & & INVTPLCY & ROA \\
\hline \multirow{3}{*}{ INVTPLCY } & Pearson Correlation & 1 & $.973^{*}$ \\
\hline & Sig. (2-tailed) & & .000 \\
\hline & $\mathrm{N}$ & 60 & 60 \\
\hline \multirow[t]{3}{*}{ ROA } & Pearson Correlation & $.973^{* *}$ & 1 \\
\hline & Sig. (2-tailed) & .000 & \\
\hline & $\mathrm{N}$ & 60 & 60 \\
\hline
\end{tabular}

**. Correlation is significant at the 0.01 level (2-tailed).

Table 4.2.2

\begin{tabular}{|l|l|l|l|}
\hline \multicolumn{2}{|l|}{ Correlations } & \multicolumn{2}{|l|}{} \\
\hline \multirow{4}{*}{ INVTPLCY } & Pearson Correlation & INVTPLCY & EPS \\
\cline { 2 - 4 } & Sig. (2-tailed) & 1 & .020 \\
\cline { 2 - 4 } & $\mathrm{N}$ & 60 & .882 \\
\hline \multirow{3}{*}{ EPS } & Pearson Correlation & .020 & 60 \\
\cline { 2 - 4 } & Sig. (2-tailed) & .882 & 1 \\
\cline { 2 - 4 } & $\mathrm{N}$ & 60 & 60 \\
\hline
\end{tabular}

Table 4.2.3

\begin{tabular}{|l|l|l|l|}
\hline \multicolumn{2}{|l|}{ Correlations } & \multicolumn{2}{l|}{} \\
\hline \multirow{4}{*}{ INVTPLCY } & Pearson Correlation & INVTPLCY & ROE \\
\cline { 2 - 4 } & Sig. (2-tailed) & 1 & -.024 \\
\cline { 2 - 4 } & $\mathrm{N}$ & 60 & .857 \\
\hline \multirow{3}{*}{ ROE } & Pearson Correlation & -.024 & 60 \\
\cline { 2 - 4 } & Sig. (2-tailed) & .857 & 1 \\
\cline { 2 - 4 } & $\mathrm{N}$ & 60 & 60 \\
\hline
\end{tabular}




\section{Table 4.2.4}

\begin{tabular}{|c|c|c|c|}
\hline \multicolumn{4}{|c|}{ Correlations } \\
\hline & & FINPLCY & ROA \\
\hline \multirow[t]{3}{*}{ FINPLCY } & Pearson Correlation & 1 & $.932^{* *}$ \\
\hline & Sig. (2-tailed) & & .000 \\
\hline & $\mathrm{N}$ & 60 & 60 \\
\hline \multirow[t]{3}{*}{ ROA } & Pearson Correlation & $.932^{* *}$ & 1 \\
\hline & Sig. (2-tailed) & .000 & \\
\hline & $\mathrm{N}$ & 60 & 60 \\
\hline
\end{tabular}

**. Correlation is significant at the 0.01 level (2-tailed).

Table 4.2.5

\begin{tabular}{|c|c|c|c|}
\hline \multicolumn{4}{|c|}{ Correlations } \\
\hline & & FINPLCY & EPS \\
\hline \multirow[t]{3}{*}{ FINPLCY } & Pearson Correlation & 1 & .019 \\
\hline & Sig. (2-tailed) & & .885 \\
\hline & $\mathrm{N}$ & 60 & 60 \\
\hline \multirow[t]{3}{*}{ EPS } & Pearson Correlation & .019 & 1 \\
\hline & Sig. (2-tailed) & .885 & \\
\hline & $\mathrm{N}$ & 60 & 60 \\
\hline
\end{tabular}

Table 4.2.6

\begin{tabular}{|l|l|l|l|}
\hline \multicolumn{2}{|l|}{ Correlations } & \multicolumn{2}{l|}{} \\
\hline \multirow{4}{*}{ FINPLCY } & Pearson Correlation & FINPLCY & ROE \\
\cline { 2 - 4 } & Sig. (2-tailed) & 1 & -.032 \\
\cline { 2 - 4 } & $\mathrm{N}$ & & .809 \\
\hline \multirow{2}{*}{ ROE } & Pearson Correlation & 60 & 60 \\
\cline { 2 - 4 } & Sig. (2-tailed) & -.032 & 1 \\
\cline { 2 - 4 } & $\mathrm{N}$ & 609 & 60 \\
\hline
\end{tabular}

**. Correlation is significant at the 0.01 level (2-tailed).

\section{Regression Analysis}

Table 4.2.7

\begin{tabular}{|l|l|l|l|l|}
\hline \multicolumn{4}{|l|}{ Model Summary } \\
\hline Model & R & R Square & Adjusted R Square & Std. Error of the Estimate \\
\hline 1 & $.973^{\text {a }}$ & .947 & .946 & .850090 \\
\hline
\end{tabular}

a. Predictors: (Constant), INVTPLCY

\begin{tabular}{|l|l|l|l|l|l|l|}
\hline \multicolumn{7}{|l|}{ ANOVA $^{\mathbf{a}}$} \\
\hline Model & Sum of Squares & df & Mean Square & F & Sig. \\
\hline \multirow{3}{*}{1} & Regression & 741.751 & 1 & 741.751 & 1026.428 & $.000^{\mathrm{b}}$ \\
\cline { 2 - 7 } & Residual & 41.914 & 58 & .723 & & \\
\cline { 2 - 7 } & Total & 783.665 & 59 & & & \\
\hline
\end{tabular}

a. Dependent Variable: ROA

b. Predictors: (Constant), INVTPLCY

\begin{tabular}{|l|l|l|l|l|l|l|}
\hline \multicolumn{2}{|l|}{ Coefficients $^{\mathbf{a}}$ Model } & \multicolumn{2}{l|}{ Unstandardized Coefficients } & Standardized Coefficients & \multirow{2}{*}{ Sig. } \\
\cline { 3 - 6 } \multicolumn{2}{|l|}{} & B & Std. Error & Beta & & \\
\hline \multirow{2}{*}{1} & (Constant) & -1.154 & .121 & & -9.562 & .000 \\
\cline { 2 - 5 } & INVTPLCY & 2.794 & .087 & .973 & 32.038 & .000 \\
\hline
\end{tabular}

a. Dependent Variable: ROA

Table 4.2.8

\begin{tabular}{|l|l|l|l|l|}
\hline \multicolumn{4}{|l|}{ Model Summary } \\
\hline Model & R & R Square & Adjusted R Square & Std. Error of the Estimate \\
\hline 1 & $.020^{\mathrm{a}}$ & .000 & -.017 & 8.344899 \\
\hline
\end{tabular}

a. Predictors: (Constant), INVTPLCY

\begin{tabular}{|l|l|l|l|l|l|l|}
\hline \multicolumn{7}{|l|}{ ANOVA $^{\mathbf{a}}$} \\
\hline Model & \multicolumn{1}{|l|}{ Sum of Squares } & df & Mean Square & F & Sig. \\
\hline \multirow{3}{*}{1} & 1.552 & 1 & 1.552 & .022 & $.882^{\text {b }}$ & 1.552 \\
\cline { 2 - 7 } & 4038.966 & 58 & 69.637 & & & 4038.966 \\
\cline { 2 - 7 } & 4040.518 & 59 & & & & 4040.518 \\
\hline
\end{tabular}

a. Dependent Variable: EPS

b. Predictors: (Constant), INVTPLCY 
"Working capital Management and Firms Financial Performance of Oil Companies in Nigeria"

a. Dependent Variable: EPS

\begin{tabular}{|c|c|c|c|c|c|c|}
\hline \multicolumn{7}{|c|}{ Coefficients $^{\mathrm{a}}$} \\
\hline \multirow{2}{*}{\multicolumn{2}{|c|}{ Model }} & \multicolumn{2}{|c|}{ Unstandardized Coefficients } & \multirow{2}{*}{$\begin{array}{l}\text { Standardized Coefficients } \\
\text { Beta }\end{array}$} & \multirow[t]{2}{*}{$\mathrm{t}$} & \multirow[t]{2}{*}{ Sig. } \\
\hline & & B & Std. Error & & & \\
\hline \multirow[t]{2}{*}{1} & (Constant) & 1.288 & 1.184 & & 1.087 & 281 \\
\hline & INVTPLCY & .128 & .856 & .020 & .149 & .882 \\
\hline
\end{tabular}

Table 4.2.9

\begin{tabular}{|l|l|l|l|l|}
\hline \multicolumn{5}{|l|}{ Model Summary } \\
\hline Model & R & R Square & Adjusted R Square & Std. Error of the Estimate \\
\hline 1 & $.024^{\mathrm{a}}$ & .001 & -.017 & 15.034315 \\
\hline
\end{tabular}

a. Predictors: (Constant), INVTPLCY

\begin{tabular}{|l|l|l|l|l|l|l|}
\hline \multicolumn{9}{|l|}{ ANOVA $^{\mathbf{a}}$} \\
\hline Model & Sum of Squares & df & Mean Square & F & Sig. \\
\hline \multirow{3}{*}{1} & Regression & 7.362 & 1 & 7.362 & .033 & $.857^{\mathbf{b}}$ \\
\cline { 2 - 8 } & Residual & 13109.776 & 58 & 226.031 & & \\
\cline { 2 - 7 } & Total & 13117.138 & 59 & & & \\
\hline
\end{tabular}

a. Dependent Variable: ROE

b. Predictors: (Constant), INVTPLCY

\begin{tabular}{|c|c|c|c|c|c|c|}
\hline \multicolumn{7}{|c|}{ Coefficients $^{\mathrm{a}}$} \\
\hline \multirow{2}{*}{\multicolumn{2}{|c|}{ Model }} & \multicolumn{2}{|c|}{ Unstandardized Coefficients } & \multirow{2}{*}{$\begin{array}{l}\text { Standardized Coefficients } \\
\text { Beta }\end{array}$} & \multirow[t]{2}{*}{$\mathrm{t}$} & \multirow[t]{2}{*}{ Sig. } \\
\hline & & $\mathrm{B}$ & Std. Error & & & \\
\hline \multirow[t]{2}{*}{1} & (Constant) & 8.044 & 2.134 & & 3.770 & .000 \\
\hline & INVTPLCY & -.278 & 1.542 & $\begin{array}{l}.024 \\
\end{array}$ & -.180 & .857 \\
\hline
\end{tabular}

a. Dependent Variable: ROE

Table 4.2.10

a. Predictors: (Constant), FINPLCY

\begin{tabular}{|l|l|l|l|l|}
\hline \multicolumn{4}{|c|}{ Table 4.2.10 } \\
\hline Model Summary & R Square & Adjusted R Square & Std. Error of the Estimate \\
\hline 1 & $.932^{\mathrm{a}}$ & .870 & .867 & 1.327806 \\
\hline
\end{tabular}

\begin{tabular}{|l|l|l|l|l|l|l|}
\hline \multicolumn{9}{|l|}{ ANOVA $^{\text {a }}$} \\
\hline Model & Sum of Squares & df & Mean Square & F & Sig. \\
\hline \multirow{3}{*}{1} & Regression & 681.407 & 1 & 681.407 & 386.489 & $.000^{\mathrm{b}}$ \\
\cline { 2 - 7 } & Residual & 102.258 & 58 & 1.763 & & \\
\cline { 2 - 7 } & Total & 783.665 & 59 & & & \\
\hline
\end{tabular}

a. Dependent Variable: ROA

b. Predictors: (Constant), FINPLCY

\begin{tabular}{|c|c|c|c|c|c|c|}
\hline \multicolumn{7}{|c|}{ Coefficients $^{\mathrm{a}}$} \\
\hline \multirow{2}{*}{\multicolumn{2}{|c|}{ Model }} & \multicolumn{2}{|c|}{ Unstandardized Coefficients } & Standardized Coefficients & \multirow[t]{2}{*}{$\mathrm{t}$} & \multirow[t]{2}{*}{ Sig. } \\
\hline & & $\mathrm{B}$ & Std. Error & Beta & & \\
\hline \multirow[t]{2}{*}{1} & (Constant) & -1.456 & .197 & & -7.392 & .000 \\
\hline & FINPLCY & 3.167 & .161 & .932 & 19.659 & .000 \\
\hline
\end{tabular}

a. Dependent Variable: ROA

Table 4.2.11

\begin{tabular}{|l|l|l|l|l|}
\hline \multicolumn{5}{|l|}{ Model Summary } \\
\hline Model & R & R Square & Adjusted R Square & Std. Error of the Estimate \\
\hline 1 & $.019^{\mathrm{a}}$ & .000 & -.017 & 8.344986 \\
\hline
\end{tabular}

a. Predictors: (Constant), FINPLCY

\begin{tabular}{|c|c|c|c|c|c|c|}
\hline \multicolumn{7}{|c|}{ ANOVA $^{a}$} \\
\hline \multicolumn{2}{|c|}{ Model } & Sum of Squares & df & Mean Square & $\mathrm{F}$ & Sig. \\
\hline \multirow[t]{3}{*}{1} & Regression & 1.468 & 1 & 1.468 & .021 & $.885^{\mathrm{b}}$ \\
\hline & Residual & 4039.050 & 58 & 69.639 & & \\
\hline & Total & 4040.518 & 59 & & & \\
\hline
\end{tabular}

a. Dependent Variable: EPS

b. Predictors: (Constant), FINPLCY 
a. Dependent Variable: EPS

\begin{tabular}{|l|l|l|l|l|l|l|}
\hline \multicolumn{2}{|l|}{ Coefficients $^{\mathbf{a}}$} \\
\hline \multicolumn{2}{|l|}{ Model } & Unstandardized Coefficients & Standardized Coefficients & $\mathrm{t}$ & Sig. \\
\cline { 3 - 8 } & B & Std. Error & Beta & & \\
\hline \multirow{2}{*}{1} & (Constant) & 1.273 & 1.238 & & 1.028 & .308 \\
\cline { 2 - 8 } & FINPLCY & .147 & 1.013 & .019 & .145 & .885 \\
\hline
\end{tabular}

Table 4.2.12

a. Predictors: (Constant), FINPLCY

\begin{tabular}{|l|l|l|l|l|}
\hline \multicolumn{4}{|l|}{ Model Summary } \\
\hline Model & R & R Square & Adjusted R Square & Std. Error of the Estimate \\
\hline 1 & $.032^{\mathrm{a}}$ & .001 & -.016 & 15.030901 \\
\hline
\end{tabular}

\begin{tabular}{|c|c|c|c|c|c|c|}
\hline \multicolumn{7}{|c|}{ ANOVA $^{\mathrm{a}}$} \\
\hline \multicolumn{2}{|c|}{ Model } & Sum of Squares & $\mathrm{df}$ & Mean Square & F & Sig. \\
\hline \multirow[t]{3}{*}{1} & Regression & 13.314 & 1 & 13.314 & .059 & $.809^{\mathrm{b}}$ \\
\hline & Residual & 13103.823 & 58 & 225.928 & & \\
\hline & Total & 13117.138 & 59 & & & \\
\hline
\end{tabular}

a. Dependent Variable: ROE

b. Predictors: (Constant), FINPLCY

\begin{tabular}{|l|l|l|l|l|l|l|}
\hline \multicolumn{2}{|l|}{ Coefficients $^{\mathbf{a}}$ Model } & \multicolumn{2}{l|}{ Unstandardized Coefficients } & Standardized Coefficients & $\mathrm{t}$ & Sig. \\
\cline { 3 - 8 } & & $\mathrm{B}$ & Std. Error & Beta & & \\
\hline \multirow{2}{*}{1} & (Constant) & 8.151 & 2.230 & & 3.656 & .001 \\
\cline { 2 - 8 } & FINPLCY & -.443 & 1.824 & -.032 & -.243 & .809 \\
\hline
\end{tabular}

a. Dependent Variable: ROE 